\title{
Editorial
}

\section{Nipah virus infection: a deadly disease emerging in India}

\author{
Ramesh Verma ${ }^{1}$, Mukesh Dhankar ${ }^{2}$, Avneet Singh ${ }^{3}$, Vinod Chayal ${ }^{1}$, Raj Kumar ${ }^{1}$, \\ Rohit Dhaka $^{1}$, Kapil Bhalla ${ }^{4}$, Ginni Agrawal ${ }^{1}$, Gopal Kumar ${ }^{1}$
}

\author{
${ }^{1}$ Department of Community Medicine, ${ }^{4}$ Department of Pediatrics, Pt B D Sharma PGIMS, Rohtak, Haryana, India \\ ${ }^{2}$ Department of Pediatrics, Lady Harding Medical College, New Delhi, India \\ ${ }^{3}$ Department of Community Medicine, CMC, Ludhiana, Punjab, India
}

\author{
*Correspondence: \\ Dr. Avneet Singh, \\ E-mail: askdr3@gmail.com
}

Copyright: (C) the author(s), publisher and licensee Medip Academy. This is an open-access article distributed under the terms of the Creative Commons Attribution Non-Commercial License, which permits unrestricted non-commercial use, distribution, and reproduction in any medium, provided the original work is properly cited.

Nipah virus infection is an emerging zoonotic disease caused by a Nipah virus (NiV) belongs to a family of Paramyxoviridae, is named after the Malaysian village of Sungai Nipah. Nipah virus was first recognized in 1998-1999 during an outbreak among pig farmers in Malaysia and Singapore when many pig farmers became ill. During this outbreak, nearly 300 human cases were reported with $30 \%$ case fatality rate and more than one million pigs were euthanized to control the outbreak. ${ }^{1}$

After 1999, no subsequent outbreaks have been reported in Malaysia or Singapore. Nipah virus was first identified as a cause of an outbreak of encephalitis in Meherpur district of Bangladesh in 2001 and found that this virus has been associated with eating raw date palm sap and with contact with infected bats or humans; since then, nearly annual outbreaks of Nipah virus encephalitis have been reported almost every year in select districts in the neighboring country. In India, two outbreaks of Nipah virus encephalitis have been reported in the eastern parts of West Bengal in the years 2001 and 2007. In these outbreaks, nearly 70 percent (50 deaths/71 cases) case fatality rate was reported. First outbreak was reported Siliguri, West Bengal in the months of January and February 2001 and second outbreak was reported in Nadia district of West Bengal in 2007. The reason of 2007 outbreak was found that a group of bats were hanging from trees near a patient's residence which suggests direct contact with bat fluids. Third outbreak of Nipah virus infection occurred in India from two districts Kozhikode and Mallapuram of Kerala on 19 May 2018. ${ }^{2}$ This is the first NiV outbreak occurred in South part of India.
In the outbreak, symptoms like acute respiratory distress syndrome and encephalitis had been observed and 17 patients were died from 19 reported cases (18 laboratory confirmed cases) from these two affected districts. Lini Puthussery, a 28-year-old nurse was also died in the outbreak because she got Nipah virus infection while caring a family of three persons during whole night that had been diagnosed with the virus. Laboratory testing was conducted by the Manipal Institute of Virus Research and the National Institute of Virology, Pune; both laboratories have advanced capacity for RT-PCR. ${ }^{3}$

Till now, no reasons of the outbreak in Kerala have been identified and epidemiological studies are going on to identify the possible reasons of that outbreak. After taking stringent containment and preventive measures like enhancement of acute fever and acute encephalitis syndrome surveillance system and strengthening of Hospital and community surveillance in Kerala by multidisciplinary team led by the Indian Government's National Centre for Disease Control (NCDC) and Health Team from state government, the situation was controlled immediately. WHO also provided technical support to the Government of India to control outbreak.

The reservoirs of Nipah virus are large abundant fruit bats of Pteropodidae family, Pteropus genus. Nipah virus is transmitted by consumption of infected raw date palm sap. Fruit bats often eat dates from palm trees and sometimes nest in wells. Few cases of human-to-human transmission were also reported among family members and health care workers who treat patients. Other possible routes of transmission for this infection include consumption of fruits partially eaten by the bats, exposure to the virus by bats or human-to-human 
transmission through hospital acquired infections. In humans, 60 per cent of NiV comes from animals and incubation period of $\mathrm{NiV}$ is 4-14 days first symptom appears in Nipah virus infected case is severe form of fever because of inflammation of brain which often leads to the state of confusion, disorientation and even persistent drowsiness, if early intervention don't take than these symptoms can even cause a coma within 24-48 hours. Most of the cases may have the sign of neurological, respiratory and pulmonary system.

\section{Possible reasons of outbreak in India}

Global warming or global change in the climate and rapid urbanisation in recent years has been responsible for this emerging infection in the country. There is rapid urbanization of animals and birds including bats because of losing their natural habitats that resulted in contacting with humans cause various outbreaks of diseases. Many ecological factors that contribute to the emergence of Nipah virus but the most common is human intervention into bat-infested areas. One school of thought that increase in the human-bat interaction in the forest could be one reason of outbreak occurred where humans drinking virus infected date palm juice contaminated by bat's urine or saliva. ${ }^{4}$

Reverse transcriptase polymerase chain reaction (RTPCR) using throat swabs, cerebrospinal fluid, urine and blood analysis during acute and convalescent stages of the disease is the diagnostic test available to detect the infection. The antibodies like IgG and IgM detection can be done after recovery to confirm the infection. Other laboratory tests are Immunohistochemistry on tissues collected during autopsy and Viral RNA isolated from the saliva of infected patients. ${ }^{5}$

Till today, there is no effective treatment or vaccine available, so all suspected cases of Nipah virus infection should be isolated so the prevention is the only option available to control of Nipah virus infection. The preventive measures like avoidance of drinking of raw palm sap (palm toddy) contaminated by bat excrete, don't consumed partially eaten fruits by bats and water from wells infested by bats and avoid exposure to bats in endemic areas and sick pigs. Bats are known to drink toddy that is collected in open containers, sometimes bats urinate in it that makes toddy contaminated with the virus. $^{6,7}$

The WHO suggests that health care professionals should wear gloves and other protective clothing during any pig slaughtering and culling procedures. Avoid contagion, the communication of disease from one person to another by close contact. Medical caregivers should employ quarantine methods and use barrier methods such as gloves, masks, and disposable gowns, as they are at high risk of person-to-person transmission of $\mathrm{NiV}$.
Surveillance and awareness are important for preventing future outbreaks. ${ }^{14,15}$ Only symptomatic treatment like intensive supportive care is recommended to treat severe respiratory and neurologic complications. In hospitals, staff should consistently implement standard infection preventive measures and control practices during patient treatment to prevent nosocomial infections. According to WHO, health staffs suspected to have NiV fever during patient caring should immediately contact local, state and national experts for guidance and immediately arrange their laboratory testing. Anti-viral drug Ribavirin has been studied in a small number of people, however benefit of this drug is unclear. ${ }^{8}$ The vaccine for the Nipah virus infection is under trial but a subunit vaccine using the Hendra $G$ glycoprotein had been trialed and found that a cross-protective antibody produced against henipavirus and nipavirus in monkeys, but till now its use in humans has not been studied. ${ }^{9}$

\section{REFERENCES}

1. AJC. Fiza Pirani, The Atlanta Journal-Constitution Updated 2018.

2. WHO. Programmes and Topics Surveillance and outbreak alert. Nipah Virus. Available from: http ://www.searo.who.int/entity/emerging_diseases/link s/nipah_virus/en. Accessed 5 July 2018.

3. WHO. Health Topic. Nipah virus infection India updates. Ministry of Health and family Welfare. Press release on 2 June 2018.Release ID 1534163. http://www.Searo.who.int/india/topics/emergencies/ Nipah-virus-infection/en. Accessed 5 July 2018.

4. Nipah virus: Third outbreak in India, here's why deadly virus has re-emerged Last Updated: May 28, 2018. Source: Moneycontrol.com. Available at: https://www.moneycontrol.com/news/trends/ current-affairs-trends/nipah-virus-third-out break-inindia-heres-why-deadly-virus-has-re-emerged2576839.html. Accessed 5 July 2018.

5. Nipah Virus (NiV) CDC". Archived from the original on 16 December 2017. Available at: www.cdc.gov. Accessed 30 June 2018.

6. Islam MS, Sazzad HM, Satter SM, Sultana S, Hossain MJ, Hasan M. Nipah Virus Transmission from Bats to Humans Associated with Drinking Traditional Liquor Made from Date Palm Sap, Bangladesh, 2011-2014. Emerg Infect Dis. 2016;22(4):664-70.

7. Balan SS. 6 Nipah virus deaths in Kerala: Batinfested house well of first victims sealed. The News Minute. Available at: https://www.thenews minute.com/article/6-nipah-virus-deaths-kerala-batinfested-house-well-first-victims-sealed-81650. Accessed 5 July 2018.

8. WHO. Emergencies preparedness, response Nipah virus - India Disease outbreak news 31 May 2018 Available at: http://www.who.int/csr/don/31-may2018-nipah-virus-india/en/. Accessed 30 June 2018.

9. Bossart KN, Rockx B, Feldmann F, Brining D, Scott D, LaCasse R, et al. A Hendra Virus G 
Glycoprotein Subunit Vaccine Protects African Green Monkeys from Nipah Virus Challenge. Sci Transl Med. 2012;4(146):146ra107.
Cite this article as: Verma R, Dhankar M, Singh A, Chayal V, Kumar R, Dhaka R, et al. Nipah virus infection: a deadly disease emerging in India. Int $\mathbf{J}$ Community Med Public Health 2018;5:4172-4. 